\title{
Exendin-4 Promotes Beta Cell Proliferation via PI3k/Akt Signalling Pathway
}

\author{
Chaoxun Wang ${ }^{a}$ Xiaopan Chen ${ }^{b}$ Xiaoying Ding ${ }^{c}$ Yanju He ${ }^{a}$ Chengying Gu ${ }^{a}$ \\ Ligang Zhou
}

aDepartment of Endocrinology, Shanghai Pudong Hospital, Fudan University Pudong Medical Center, Shanghai, 'Department of Endocrinology, Affiliated Hospital of Hainan Medical College, Haikou, 'Department of Endocrinology, Shanghai First People's Hospital, Shanghai Jiaotong University, Shanghai, China

\section{Key Words}

Exendin-4 $\bullet$ Incretin • Diabetes $•$ Beta-cell proliferation $•$ PI3k/Akt

\begin{abstract}
:
Background/Aims: Prevention of diabetes requires maintenance of a functional beta-cell mass, the postnatal growth of which depends on beta cell proliferation. Past studies have shown evidence of an effect of an incretin analogue, Exendin-4, in promoting beta cell proliferation, whereas the underlying molecular mechanisms are not completely understood. Methods: Here we studied the effects of Exendin-4 on beta cell proliferation in vitro and in vivo through analysing BrdU-incorporated beta cells. We also analysed the effects of Exendin-4 on beta cell mass in vivo, and on beta cell number in vitro. Then, we applied specific inhibitors of different signalling pathways and analysed their effects on Exendin-4-induced beta cell proliferation. Results: Exendin-4 increased beta cell proliferation in vitro and in vivo, resulting in significant increases in beta cell mass and beta cell number, respectively. Inhibition of PI3K/ Akt signalling, but not inhibition of either ERK/MAPK pathway, or JNK pathway, significantly abolished the effects of Exendin-4 in promoting beta cell proliferation. Conclusion: Exendin-4 promotes beta cell proliferation via PI3k/Akt signaling pathway.
\end{abstract}

Chaoxun Wang

or Ligang Zhou

\section{KARGER 125}

Department of Endocrinology, Shanghai Pudong Hospital, Fudan University Pudong Medical Center, 2800 Gongwei Road, Shanghai 201399 (China)

Tel. +862158022995, E-mail chaoxun_wang@163.com or xunshdonger@hotmail.com, E-Mail ligang.zhou@gmail.com 


\section{Introduction}

Preservation and restoration of a functional beta-cell mass are effective therapies for diabetes [1]. Thus, understanding of the molecular mechanisms underlying the regulation of beta cell mass in the adult pancreas may substantially boost diabetic research and treatment. During embryonic pancreatic formation, both beta-cell proliferation and beta-cell neogenesis (from pancreatic endocrine progenitor cells that express Neurog3) contribute to the generation of beta cell mass [2-4]. However, postnatal beta cell growth has been demonstrated predominantly attributable to beta cell proliferation [5-15].

Incretins are gut-derived circulating peptide hormones that potentiate glucosedependent insulin secretion following meal uptake [16-19]. Glucagon-like peptide-1 (GLP1) and glucose-dependent insulinotropic polypeptide (GIP) are two major incretins for controlling the secretion of insulin, glucagon and somatostatin to regulate glucose metabolism through glucose disposal [16]. GLP-1 and GIP are terminated through enzymatic cleavage by dipeptidyl peptidase-4 (DPP-4) followed by renal clearance [16]. So far, it is known that GLP1 and GIP function predominantly through unique $\mathrm{G}$ protein-coupled receptors expressed on beta cells and some non-beta cells [16], whereas the accurate localization of GLP-1 and GIP receptors is not solved due to poor specificity and sensitivity of the available antisera. GLP1 and GIP have been shown to promote beta cell proliferation and survival in rodents [16]. However, the underlying molecular basis is not completely understood.

Exendin-4 is a 39-amino-acid GLP-1 agonist, a potential insulin secretagogue that belongs to the group of incretin mimetics [17-19]. Exendin-4 has been approved for the treatment of type 2 diabetes in 2005 [17-19]. In its pharmaceutical form, Exendin-4 is subcutaneously administered under the skin of the abdomen, thigh, or arm, any time within the 60 minutes before the first and last meal of the day [17-19]. Exendin-4 shares extensive homology and function with mammalian GLP-1, but has a therapeutic advantage in its resistance to degradation by DPP-IV, which breaks down GLP-1 in mammals, resulting in a significantly longer pharmacological half-life [17-19]. Past studies have shown evidence of an effect of Exendin-4 in promoting beta cell proliferation [20-27], but the studies on the underlying molecular mechanisms are not complete.

Here, we show that Exendin-4 increased beta cell proliferation in vitro and in vivo, resulting in significant increases in beta cell mass and beta cell number, respectively. Inhibition of PI3K/Akt signalling, but not inhibition of either ERK/MAPK pathway, or JNK pathway, significantly abolished the effects of Exendin-4 in promoting beta cell proliferation. Thus, Exendin-4 promotes beta cell proliferation via PI3k/Akt signalling pathway.

\section{Materials and Methods}

Mouse handling

All animal experiments were performed according to the USA National Institute of Health Guide for the Care and Use of Laboratory Animals, and the protocols were approved by the Ethics Committee for Experimental Research, Shanghai Pudong Hospital of Fudan University Pudong Medical Center. Female C57BL/C mice of 12 weeks of age were purchased from the National Resource Center of Model Mice (Nanjing, China). Mice were housed in Pathogen-free environment.

Exendin-4 injection

Exendin-4 (Peninsula Labs, Belmont, CA, USA) was daily intraperitoneally injected to the mice at a dose of $1 \mathrm{nmol} / \mathrm{kg}$ body weight) continuously for 7 days. Phosphate-buffered saline (PBS) of same volume was injected to control mice as a sham treatment.

BrdU labeling

For quantification of beta-cell proliferation, $1 \mathrm{mg} / \mathrm{ml}$ BrdU (bromodeoxyuridine, Sigma-Aldrich, St. Louis, MO, USA) was added into $1 \%$ sucrose drinking water, and then given to mice since the first injection 


\section{Cellular Physiology Cell Physiol Biochem 2015;35:2223-2232 \begin{tabular}{ll|l} 
and Bol: 10.1159/000374027 & $\begin{array}{l}\text { O 2015 S. Karger AG, Basel } \\
\text { www.karger.com/cpb }\end{array}$ \\
\hline
\end{tabular} \\ Wang et al.: Exendin-4 Promotes Beta Cell Proliferation}

of Exendin-4 for seven days till sacrifice of the mice, as has been described before [28-31]. Ten mice were analysed in each experimental condition (Exendin-4-treated group and sham-treated group).

Islet isolation

The mouse pancreas was first perfused with $0.125 \mathrm{mg} / \mathrm{ml}$ LiberaseTL (Roche, Nutley, NJ, USA) from the biliary-pancreatic bile duct, then was incubated in $0.125 \mathrm{mg} / \mathrm{ml}$ LiberaseTL in a $37^{\circ} \mathrm{C}$ shaker at $200 \mathrm{rpm}$ for 45 minutes. Histopaque1077 and Histopaque1119 (Sigma-Aldrich, USA) were mixed at a ratio of 9:33 (vol:vol) to generate Histopaque1110. Centrifugation in Histopaque1100 at 1200rpm for 15 minutes without brake (islets are in the solution fraction), following by hand-pickings, was then performed to isolate islets.

\section{Islet culture and inhibitors}

Mouse islets were kept in RPMI 1640 medium (Invitrogen, Carlsbad, CA, USA) supplemented with $10 \%$ fetal bovine serum (FBS; Invitrogen), $4.5 \mathrm{~g} / \mathrm{l}$ glucose, and penicillin/streptomycin mixture (Invitrogen).

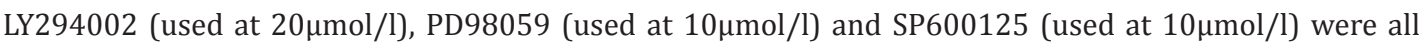
purchased from Sigma-Aldrich, and dissolved in dimethyl sulfoxide (DMSO, Sigma-Aldrich). They were used to inhibit phosphorylation of PI3K/Akt, ERK/MAPK and JNK pathway in Exendin-4-treated cultured islets, respectively.

\section{Immunohistochemistry and immunocytochemistry}

Mouse pancreata were dissected out and fixed with 4\% paraformaldehyde (Sigma-Aldrich) for 6 hours, and then cyro-protected in 30\% sucrose for 24 hours. Frozen samples were then sectioned in $6 \mu \mathrm{m}$. Cultured islets were spin down, embedded in OCT, and sectioned in $6 \mu \mathrm{m}$. Primary antibodies used in immunohistochemistry are guinea pig polyclonal anti-insulin (1:300) (Abcam, Cambridge, MA, USA), rat polyclonal anti-BrdU (1:100) (Abcam), and mouse monoclonal anti-glucagon (1:500) (Sigma-Aldrich). For BrdU staining, antigen retrieval was performed by incubation of the slides with $1 \mathrm{~mol} / \mathrm{l} \mathrm{HCl}$ at room temperature for 40 minutes. Secondary antibodies were Cy3-, Cy2- and Cy5- conjugated antibodies for corresponding species (Jackson Labs, Bar Harbor, ME, USA). DAPI (4',6-diamidino-2-phenylindole, SigmaAldrich) was used to stain nuclei.

\section{Quantification of beta-cell proliferation and apoptosis}

Insulin staining was used to identify beta cells. BrdU staining was used to identify S-phase proliferating cells. Terminal deoxynucleotidyltransferase-mediated dUTP-biotin nick end labeling (Tunel) staining was performed with an ApopTag® Peroxidase In Situ Apoptosis Detection Kit (Millipore, Billerica, MA, USA), according to the manufacturer's instruction. The quantification of BrdU+ beta cells or Tunel+ beta cells in vivo was based on 6 sections that were $150 \mu \mathrm{m}$ apart from each other. More than 2000 beta cells were counted in each animal. Ten mice were measured in each experimental condition. The quantification of BrdU+ beta cells in vitro were based on more than 2000 beta cells. Each experimental condition contained t10 repeats.

\section{Quantification of beta cell mass}

The quantification of beta cell mass was done as has been described before [8]. Briefly, the pancreata were weighed and then fixed with 4\% Paraformaldehyde for 6 hours, and then cyro-protected in 30\% sucrose for 24 hours in a way to allow longitudinal sections from tail to head of the pancreas to be obtained. Sections at $150 \mu \mathrm{m}$ intervals from whole pancreas were immunostained for insulin and analysed using NIH Image J software. The relative cross-sectional area of beta cells was determined by quantification of the cross-sectional area occupied by beta cells divided by the cross-sectional area of total tissue. The beta-cell mass per pancreas was estimated as the product of the relative cross-sectional area of beta cells per total tissue and the weight of the pancreas. The beta-cell mass was calculated by examining pancreata from 10 animals for each group.

Cell growth assay

A diphenyltetrazolium bromide (MTT) assay was performed to determine cell growth. Fifty islets per well were seeded, treated w/o Exendin- 4 and w/o inhibitors, and allowed to grow for 48 hours. Afterwards, 


\section{Cellular Physiology Cell Physiol Biochem 2015;35:2223-2232 \begin{tabular}{c|c|c|}
\hline DOI: 10.1159/000374027 & O 2015 S. Karger AG, Basel
\end{tabular} www.karger.com/cpb

the media were removed and the islets were washed with PBS, after which $5 \mathrm{~g} / \mathrm{l}$ of MTT (Amersco, Indianapolis, IN, USA) was added to each well. Four hours later, MTT was removed and $150 \mu$ l of DMSO was added. The viability of the cells was calculated from the absorption at $570 \mathrm{~nm}$ with an enzyme-linked immunosorbent assay reader.

\section{$R T-q P C R$}

RNA was extracted from islet-deprived pancreatic cells with Trizol (Invitrogen) and used for cDNA synthesis. Quantitative PCR were performed in duplicates with QuantiTect SYBR Green PCR Kit (Qiagen, Hilden, Germany). Neurog3 primers are: forward: 5'-tctcaagcatctcgcctcttc-3' and reverse: 5'-acagcaagggtaccgatgaga-3'. GAPDH primers are: forward: 5'-aactttggcattgtggaagg-3' and reverse: 5'-acacattgggggtaggaaca-3'. Values of Neurog3 were normalized against GAPDH, then compared with controls.

Statistics

All values are depicted as mean \pm standard error from 10 individuals and are considered significant if $\mathrm{p}<0.05$. All data were statistically analysed using one-way ANOVA with a Bonferoni correction.

\section{Results}

\section{Exendin-4 increased beta cell proliferation in vivo}

First, we gave mice Exendin- 4 to examine its effects on beta cell proliferation. Exendin-4 was daily intraperitoneally injected at a dose of $1 \mathrm{nmol} / \mathrm{kg}$ body weight continuously for 7 days. PBS of same volume was injected to control mice as a sham treatment. To quantify beta cell proliferation, BrdU was added into drinking water to the mice since the first injection of Exendin-4 for seven days till sacrifice. We found that the BrdU+ beta cells in sham-treated mice were $1.2 \pm 0.2 \%$, while the BrdU+ beta cells in Exendin-4-treated mice were $12.5 \pm 1.6 \%$, shown by representative images (Fig. 1), and by quantification (Fig. 2A). The increases in beta cell proliferation were significant $(p<0.05, n=10$, one-way ANOVA with a Bonferoni correction). However, Exendin-4 did not significantly affect beta cell apoptosis (Fig. 2B). Moreover, the increases in beta cell proliferation by Exendin-4 resulted in a significant increase in beta cell mass (Fig. 2C, 1.7 $\pm 0.2 \mathrm{mg}$ in Exendin-4-treated mouse pancreas vs $1.4 \pm 0.15 \mathrm{mg}$ in sham-treated mouse pancreas, $\mathrm{p}<0.05, \mathrm{n}=10$, one-way ANOVA with a Bonferoni correction). To examine whether beta-cell neogenesis may be involved, we examined the Neurog3 levels in islet-deprived pancreas, and found that Exendin-4 did not significantly affect Neurog3 levels in exocrine pancreas (Fig. 2D). These data suggest that beta-cell neogenesis does not occur after Exendin-4 treatment. Together, these data suggest that Exendin-4 increases beta cell proliferation in vivo.

\section{Exendin-4 increased beta cell proliferation in vitro}

In order to study the molecular mechanisms underlying the effects of Exendin-4 in promoting beta cell proliferation in vivo, we examined whether Exendin-4 may similarly increase beta cell proliferation in vitro. Exendin-4 was then given to isolated primary mouse islets, and BrdU was given to label S-phase proliferating beta cells for 48 hours. We found that the BrdU+ beta cells in control islets were $2.5 \pm 0.3 \%$, while the BrdU+ beta cells in Exendin-4-treated islets were $28.7 \pm 3.1 \%$, shown by representative images (Fig. 3 ), and by quantification (Fig. 4A). The increases in beta cell proliferation were significant $(\mathrm{p}<0.05$, $n=10$, one-way ANOVA with a Bonferoni correction). Moreover, the increases in beta cell proliferation by Exendin-4 resulted in a significant increase in beta cell number (Fig. 4B, Exendin-4-treated mouse islets vs sham-treated islets, $\mathrm{p}<0.05, \mathrm{n}=10$, one-way ANOVA with a Bonferoni correction) in a MTT assay. Together, these data suggest that Exendin-4 increases beta cell proliferation in vitro.

\section{KARGER}


Fig. 1. Detection of proliferating beta cells by immunohistochemistry. Exendin-4 and BrdU were given to the mice continuously for 7 days. BrdU and insulin double staining was then performed. Representative images of immunohistochemistry for insulin (INS) and BrdU were shown. DAPI: nuclear staining. Sham: no Exendin-4. *: Scale bar is $20 \mu \mathrm{m}$.

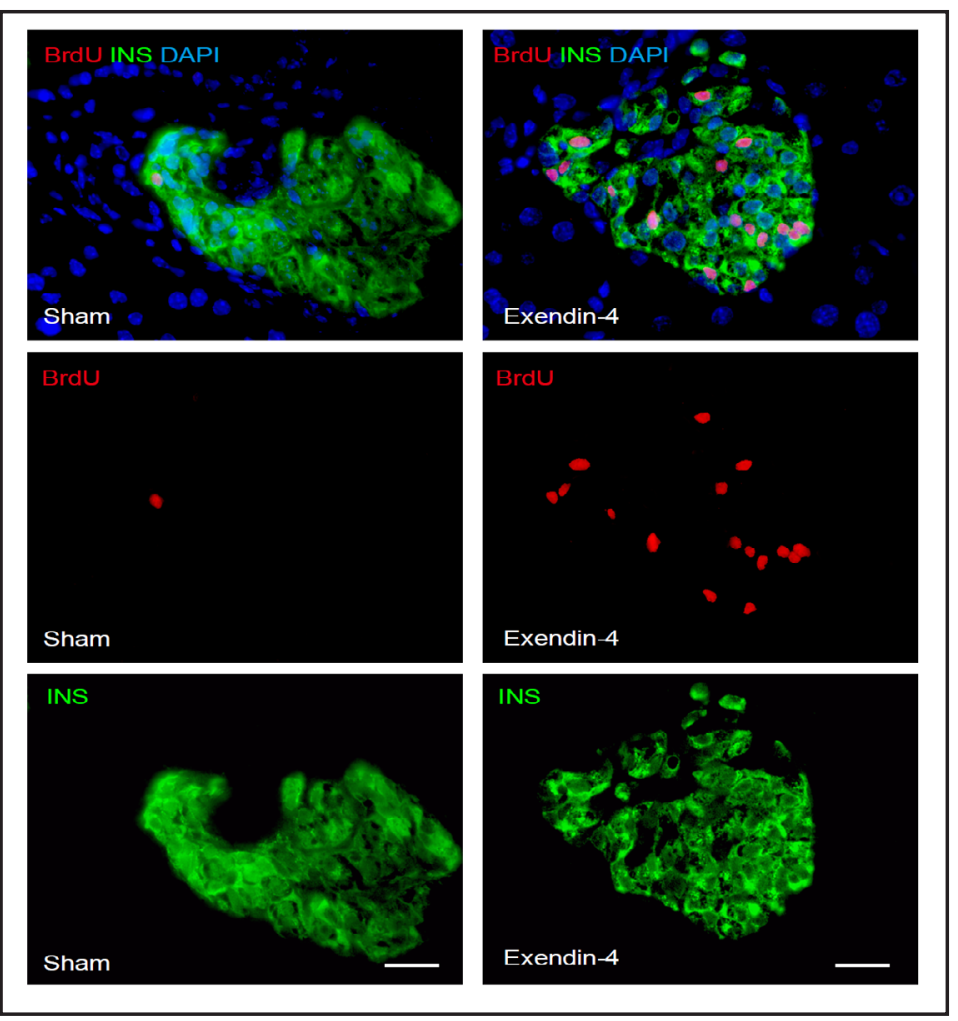

Fig. 2. Exendin-4 increased beta cell proliferation in vivo. Exendin-4 and BrdU were given to the mice continuously for 7 days. BrdU and insulin double staining was then performed. (A) Quantification of BrdU+ beta cells. (B) Quantification of apoptotic cells by TUNEL staining. (C) Beta-cell mass. (D) RT-qPCR for Neurog3 transcript (normalized to GAPDH) in islet-deprived pancreas. Sham: no Exendin-4. *: $\mathrm{p}<0.05$. $\mathrm{n}=10$. Statistic: one-way ANOVA with a Bonferoni correction.

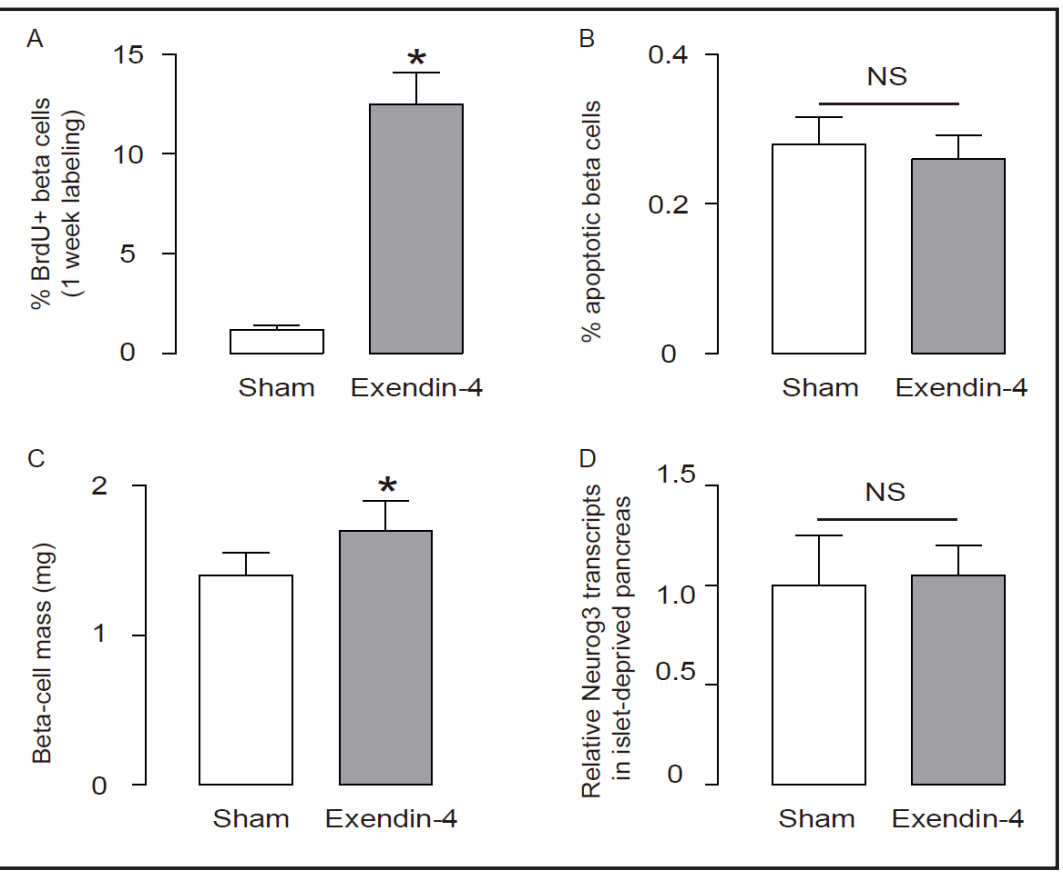

Exendin-4 increased beta cell proliferation via PI3k/Akt signaling pathway

Different signaling pathways including ERK/MAPK, JNK and PI3k/Akt pathways may be responsible for transduction of signaling to trigger beta cell proliferation by Exendin- 4 . In order to determine the underlying molecular mechanisms, we gave Exendin-4-treated mouse islets either with $10 \mu \mathrm{mol} / \mathrm{l}$ PD98059, a specific inhibitor to ERK1/2, to inhibit ERK/ MAPK signal transduction cascades, or $10 \mu \mathrm{mol} / \mathrm{l}$ SP600125, a specific inhibitor to JNK, to inhibit JNK signal transduction cascades, or $20 \mu \mathrm{mol} / \mathrm{l}$ LY294002, a specific inhibitor to Akt

\section{KARGER}


Fig. 3. Immunocytochemistry staining for insulin, glucagon and BrdU in Exendin-4-treated islets. Exendin- 4 and BrdU were given to cultured mouse islets for 48 hours. Inhibitors PD98059, LY294002 and SP600125 were given to inhibit certain signaling pathways. BrdU, insulin (INS) and glucagon (GLU) triple staining was then performed. Representative images of immunocytochemistry for INS, GLU and BrdU were shown. Control: no treatment. Scale bar is $40 \mu \mathrm{m}$.
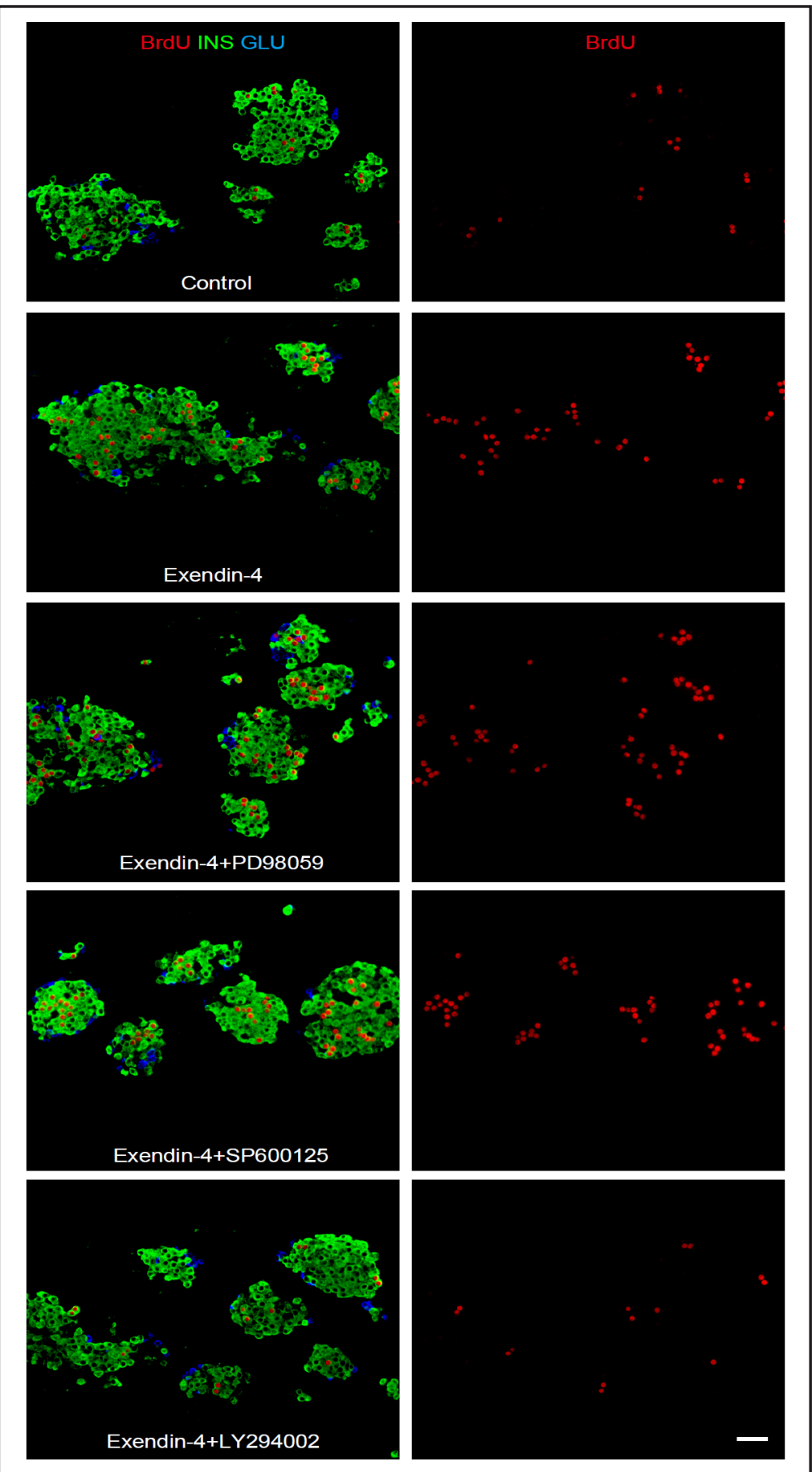

(a key component in PI3k pathway), to inhibit PI3K/Akt downstream signaling cascades, and then checked their effects on Exendin-4-induced increases in beta cell proliferation in vitro.

We found that only LY294002 significantly inhibited the effects of Exendin-4 in promoting beta cell proliferation, shown by representative images (Fig. 3), and by quantification (Fig. $4 \mathrm{~A}, \mathrm{p}<0.05, \mathrm{n}=10$, one-way ANOVA with a Bonferoni correction). Moreover, the inhibitory effect of LY294002 on Exendin-4-induced increases in beta cell proliferation resulted in a significant reduction in the increases in beta cell number (Fig. 4B, $p<0.05, n=10$, one-way ANOVA with a Bonferoni correction) in a MTT assay. Together, these data suggest that Exendin-4 increases beta cell proliferation via PI3k/Akt signalling pathway. This model is thus summarized in a schematic (Fig. 5). 


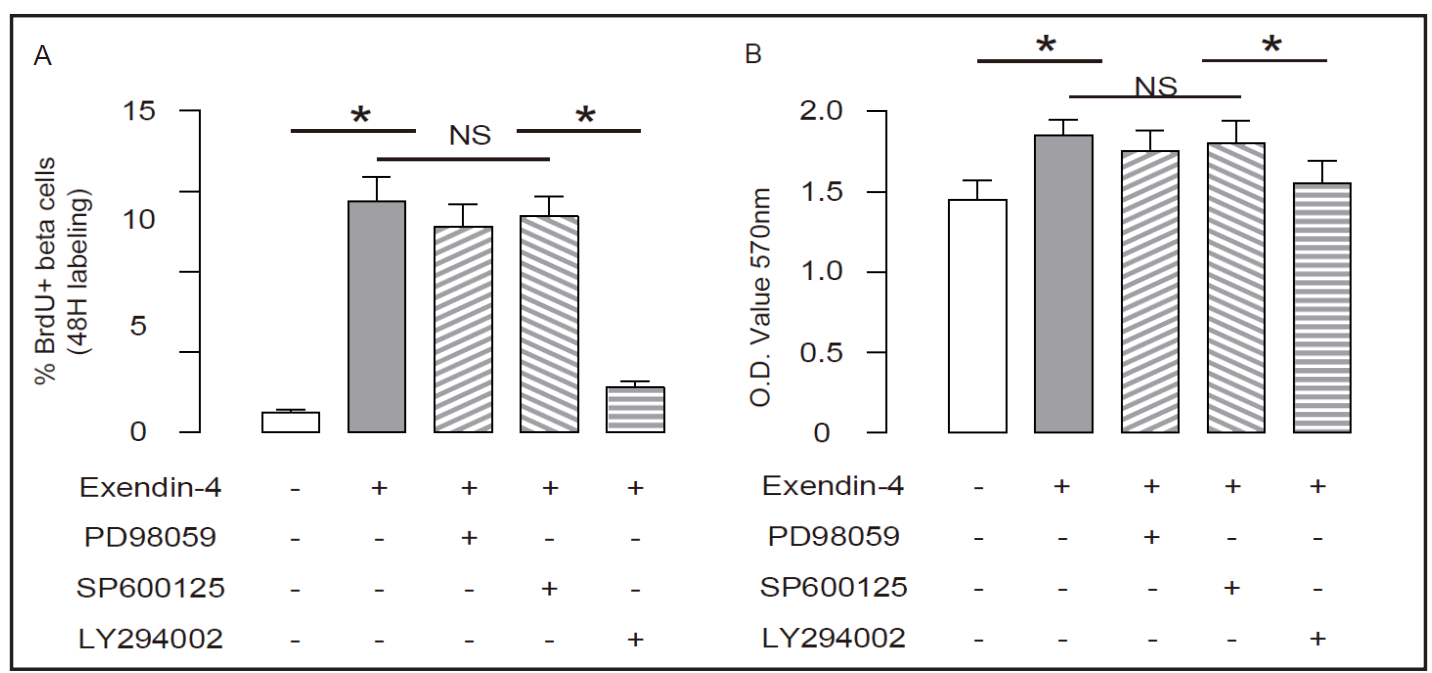

Fig. 4. Exendin-4 increased beta cell proliferation via PI3K/Akt signalling pathway in vitro. Exendin-4 and BrdU were given to cultured mouse islets for 48 hours. Inhibitors PD98059, LY294002 and SP600125 were given to inhibit certain signaling pathways. BrdU, insulin (INS) and glucagon (GLU) triple staining was then performed. (A) Quantification of BrdU+ beta cells. (C) MTT assay to evaluate cell number. *: p<0.05. NS: non-significant. $\mathrm{n}=10$. Statistic: one-way ANOVA with a Bonferoni correction.

Fig. 5. Schematic of the model. Exendin-4 increases beta cell proliferation via PI3k/Akt signaling pathway.

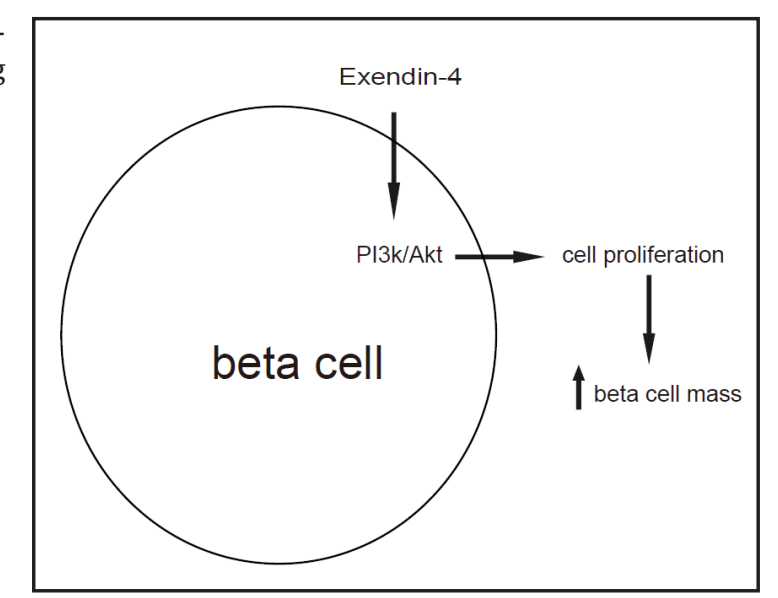

\section{Discussion}

Results of clinical studies assessing whether Exendin-4 preserves $\beta$-cell function in subjects with diabetes seem to be negative [16-19]. However, an essential role of Exendin-4 in promoting beta cell proliferation and in suppressing beta cell apoptosis, leading to the expansion of $\beta$-cell mass, has been highlighted [20-27]. Anti-apoptotic actions of Exendin-4 have been shown in rodent and human islets and in preclinical studies of islet transplantation [20-27]. Nevertheless, none of these studies have even examined the involvement of different signaling pathways [20-27]. Thus, we were prompted to approach this question in the current study.

Here, we show that Exendin-4 increased beta cell proliferation based on BrdU incorporation in vitro and in vivo, resulting in significant increases in beta cell mass and beta cell number, respectively. BrdU specifically labelled S-phase proliferating cells. Thus, a continuous provision of BrdU (7 days in vivo, or 48 hours in vitro) essentially labelled all proliferating cells in the corresponding period, which allows more positive cells to be detected at analysis, as an advantage over short-term BrdU labelling [28-31].

Although the increases in the beta cell mass or number are modest, it may largely result from the intervention period as short as 7 days in vivo, or 48 hours in vitro. Since KARGER 


\section{Cellular Physiology Cell Physiol Biochem 2015;35:2223-2232 \begin{tabular}{l|l|l|}
\hline DOI: 10.1159/000374027 & (0) 2015 S. Karger AG, Basel
\end{tabular}

an anti-apoptotic effect of Exendin-4 has been reported [20-27], it can be expected that longer treatment with Exendin-4 may further increase beta cell mass or number. Another possibility for the relative modest increases in beta cell proliferation and beta cell mass by Exendin-4 may be due to the systemic glucose metabolic control. Since the existing beta cells were not harmed at the time of Exendin-4 treatment, and it is well-known that beta cell mass is tightly regulated for metabolic need, thus the increases in beta cell proliferation and subsequently increases in beta cell mass induced by Exendin- 4 may be attenuated by the systemic control, as increased beta cell mass is not necessary in our experimental setting. In line with this notion, in case of beta cell shortage, the effects of Exendin- 4 in promoting beta cell proliferation may be substantialized, as has shown previously in diabetes or in beta cell loss [20-27].

ERK/MAPK, JNK and PI3k/Akt pathways may be responsible for signal transduction to trigger beta cell proliferation by Exendin-4. The most frequently applied methods to determine the possible involvement of these pathways were to use loss-of-function approaches to inhibit the target pathways by specific inhibitors. Here, PD98059 is a specific inhibitor to ERK1/2 for suppressing ERK/MAPK, SP600125 is a specific inhibitor to JNK pathway, and LY294002 is a specific inhibitor to Akt for suppressing PI3K/Akt downstream signaling cascades. We found that only LY294002 significantly inhibited the effects of Exendin-4 in promoting beta cell proliferation, and subsequently the increases in beta cell number. It is well-known that Akt activation may induce cell proliferation through phosphorylation modification of either mTor, or Fox01, which directly regulates cell-cycle activators and inhibitors, e.g. Cyclins, CDKs, p21 and p27 [31-34]. Since the precise signalling cascades downstream Akt signalling may be cell-type dependent [31-34], future work may be applied to address these questions.

Since we show that Exendin-4 promotes beta cell proliferation both in vivo and in vitro, it seemed that the effects of Exendin-4 in promoting beta cell proliferation are at least partially conducted directly, and do not require involvement of other cell types. Thus, Exendin-4 should activate PI3k/Akt signalling pathway in beta cells by directly ligand-binding-driven activation of receptor signalling.

Together, our work should provide novel information on the molecular basis of Exendin4-induced increases in beta cell mass, which sheds new insights into the use of Exendin-4 as a beta cell trophic factor for treating diabetes.

\section{Disclosure Statement}

None disclosed.

\section{Acknowledgement}

This work was funded by Research Grant for Health Science and Technology of Pudong Municipal Commission of Health and Family Planning of Shanghai (Grant No.PW2014A-27) and the National Natural Science Foundation of China (Grant No. 81370932).

\section{Reference}

1 Weir GC, Bonner-Weir S: Islets of langerhans: The puzzle of intraislet interactions and their relevance to diabetes. J Clin Invest 1990;85:983-987.

2 Murtaugh LC, Melton DA: Genes, signals, and lineages in pancreas development. Annu Rev Cell Dev Biol 2003;19:71-89.

3 Zaret KS, Grompe M: Generation and regeneration of cells of the liver and pancreas. Science 2008;322:1490-1494. 


\section{Cellular Physiology Cell Physiol Biochem 2015;35:2223-2232 \begin{tabular}{l|l} 
DOI: 10.1159/000374027 & (C) 2015 S. Karger AG, Basel
\end{tabular} www.karger.com/cpb \\ Wang et al.: Exendin-4 Promotes Beta Cell Proliferation}

4 Edlund H: Pancreatic organogenesis--developmental mechanisms and implications for therapy. Nat Rev Genet 2002;3:524-532.

5 Dor Y, Brown J, Martinez OI, Melton DA: Adult pancreatic beta-cells are formed by self-duplication rather than stem-cell differentiation. Nature 2004;429:41-46.

6 Teta M, Rankin MM, Long SY, Stein GM, Kushner JA: Growth and regeneration of adult beta cells does not involve specialized progenitors. Dev Cell 2007;12:817-826.

7 Meier JJ, Butler AE, Saisho Y, Monchamp T, Galasso R, Bhushan A, Rizza RA, Butler PC: Beta-cell replication is the primary mechanism subserving the postnatal expansion of beta-cell mass in humans. Diabetes 2008;57:1584-1594.

8 Georgia S, Bhushan A: Beta cell replication is the primary mechanism for maintaining postnatal beta cell mass. J Clin Invest 2004;114:963-968.

9 Xiao X, Chen Z, Shiota C, Prasadan K, Guo P, El-Gohary Y, Paredes J, Welsh C, Wiersch J, Gittes GK: No evidence for beta cell neogenesis in murine adult pancreas. J Clin Invest 2013;123:2207-2217.

10 Johansson M, Mattsson G, Andersson A, Jansson L, Carlsson PO: Islet endothelial cells and pancreatic betacell proliferation: Studies in vitro and during pregnancy in adult rats. Endocrinology 2006;147:2315-2324.

11 Butler AE, Cao-Minh L, Galasso R, Rizza RA, Corradin A, Cobelli C, Butler PC: Adaptive changes in pancreatic beta cell fractional area and beta cell turnover in human pregnancy. Diabetologia 2010;53:2167-2176.

12 Rieck S, Kaestner KH: Expansion of beta-cell mass in response to pregnancy. Trends Endocrinol Metab 2010;21:151-158.

13 Schraenen A, de Faudeur G, Thorrez L, Lemaire K, Van Wichelen G, Granvik M, Van Lommel L, in't Veld P, Schuit F: Mrna expression analysis of cell cycle genes in islets of pregnant mice. Diabetologia 2010;53:2579-2588.

14 Xue Y, Liu C, Xu Y, Yuan Q, Xu K, Mao X, Chen G, Wu X, Brendel MD, Liu C: Study on pancreatic islet adaptation and gene expression during pregnancy in rats. Endocrine 2010;37:83-97.

15 Zhao X: Increase of beta cell mass by beta cell replication, but not neogenesis, in the maternal pancreas in mice. Endocr J 2014;61:623-628.

16 Drucker DJ: Incretin action in the pancreas: Potential promise, possible perils, and pathological pitfalls. Diabetes 2013;62:3316-3323.

17 Lovshin JA, Drucker DJ: Incretin-based therapies for type 2 diabetes mellitus. Nat Rev Endocrinol 2009;5:262-269.

18 Amori RE, Lau J, Pittas AG: Efficacy and safety of incretin therapy in type 2 diabetes: Systematic review and meta-analysis. JAMA 2007;298:194-206.

19 Drucker DJ, Nauck MA: The incretin system: Glucagon-like peptide-1 receptor agonists and dipeptidyl peptidase-4 inhibitors in type 2 diabetes. Lancet 2006;368:1696-1705.

20 Heller C, Kuhn MC, Mulders-Opgenoorth B, Schott M, Willenberg HS, Scherbaum WA, Schinner S: Exendin-4 upregulates the expression of wnt-4, a novel regulator of pancreatic beta-cell proliferation. Am J Physiol Endocrinol Metab 2011;301:E864-872.

21 Perez-Arana G, Blandino-Rosano M, Prada-Oliveira A, Aguilar-Diosdado M, Segundo C: Decrease in \{beta\}-cell proliferation precedes apoptosis during diabetes development in bio-breeding/worcester rat: Beneficial role of exendin-4. Endocrinology 2010;151:2538-2546.

22 Arakawa M, Ebato C, Mita T, Hirose T, Kawamori R, Fujitani Y, Watada H: Effects of exendin-4 on glucose tolerance, insulin secretion, and beta-cell proliferation depend on treatment dose, treatment duration and meal contents. Biochem Biophys Res Commun 2009;390:809-814.

23 Aviv V, Meivar-Levy I, Rachmut IH, Rubinek T, Mor E, Ferber S: Exendin-4 promotes liver cell proliferation and enhances the pdx-1-induced liver to pancreas transdifferentiation process. J Biol Chem 2009;284:33509-33520.

24 Song WJ, Schreiber WE, Zhong E, Liu FF, Kornfeld BD, Wondisford FE, Hussain MA: Exendin-4 stimulation of cyclin a2 in beta-cell proliferation. Diabetes 2008;57:2371-2381.

25 Xie J, El Sayed NM, Qi C, Zhao X, Moore CE, Herbert TP: Exendin-4 stimulates islet cell replication via the igf1 receptor activation of mtorc1/s6k1. J Mol Endocrinol 2014;53:105-115.

26 Tian L, Gao J, Weng G, Yi H, Tian B, O'Brien TD, Guo Z: Comparison of exendin-4 on beta-cell replication in mouse and human islet grafts. Transpl Int 2011;24:856-864. 
27 Xu G, Stoffers DA, Habener JF, Bonner-Weir S: Exendin-4 stimulates both beta-cell replication and neogenesis, resulting in increased beta-cell mass and improved glucose tolerance in diabetic rats. Diabetes 1999;48:2270-2276.

28 Rankin MM, Kushner JA: Adaptive beta-cell proliferation is severely restricted with advanced age. Diabetes 2009;58:1365-1372.

29 Teta M, Long SY, Wartschow LM, Rankin MM, Kushner JA: Very slow turnover of beta-cells in aged adult mice. Diabetes 2005;54:2557-2567.

30 Xiao X, Wiersch J, El-Gohary Y, Guo P, Prasadan K, Paredes J, Welsh C, Shiota C, Gittes GK: Tgfbeta receptor signaling is essential for inflammation-induced but not beta-cell workload-induced beta-cell proliferation. Diabetes 2013;62:1217-1226.

31 Xiao X, Gaffar I, Guo P, Wiersch J, Fischbach S, Peirish L, Song Z, El-Gohary Y, Prasadan K, Shiota C, Gittes GK: M2 macrophages promote beta-cell proliferation by up-regulation of smad7. Proc Natl Acad Sci U S A 2014;111:E1211-1220.

32 Yang W, Zhang Y, Li Y, Wu Z, Zhu D: Myostatin induces cyclin d1 degradation to cause cell cycle arrest through a phosphatidylinositol 3-kinase/akt/gsk-3 beta pathway and is antagonized by insulin-like growth factor 1. J Biol Chem 2007;282:3799-3808.

33 Shelton JG, Blalock WL, White ER, Steelman LS, McCubrey JA: Ability of the activated pi3k/akt oncoproteins to synergize with mek1 and induce cell cycle progression and abrogate the cytokine-dependence of hematopoietic cells. Cell Cycle 2004;3:503-512.

34 Schmidt M, Fernandez de Mattos S, van der Horst A, Klompmaker R, Kops GJ, Lam EW, Burgering BM, Medema RH: Cell cycle inhibition by foxo forkhead transcription factors involves downregulation of cyclin d. Mol Cell Biol 2002;22:7842-7852. 